\title{
Penilaian Kemiskinan Partisipatif pada Kawasan Transisi Perdesaan ke Perkotaan di Kabupaten Sragen
}

\author{
Participatory Poverty-Assessment in Rural-Urban Transitional Area \\ in Sragen Regency
}

\author{
PRITA RAMADIANI ${ }^{1}{ }^{*}$, FADJAR HARI MARDIANSJAH ${ }^{1}$ \\ ${ }^{1}$ Departemen Perencanaan Wilayah dan Kota Universitas Diponegoro, Jl. Prof. H. Soedarto, SH Semarang; \\ *Penulis korespondensi, e-mail: pritaramadiani@gmail.com \\ (Diterima: 14 Oktober 2016; Disetujui: 30 November 2016)
}

\begin{abstract}
Poverty in rural-urban transitional area has distinct characteristics from those in urban or rural poverty. This phenomenon can also be seen in Sragen Regency, peri-urban of Solo Raya. A descriptive analysis based on participatory poverty-assessment is conducted in this research in order to understand the poors in the transitional area. A set of questions was given to 100 poor households in urban agglomeration of Sragen. The main finding confirms that 29 households have better livelihood compared to 10 years ago, even though the improvements has not come as expected. Unequal distribution and different accessibility among community groups for urban facilities are identified as the common problems, as well as low standard of urban infrastructures provision in several neighborhoods which requires improvement. The increase of job opportunities is not followed significantly by occupational shift of the poors because of their limited competency and ability. Having this context, policies in such areas should not only related to urban facilities, infrastructures, as well as the living environment provision and improvement, but also needs some elements that focus on labor development, including improvement of competency and asset utilization for business development. These policies are needed in order to improve the quality of urban living environment without compromising the poor's ability to compete in the rural-urban transitional situation.
\end{abstract}

Keywords: participatory poverty-assesment, poverty, rural to urban transition, Sragen agglomeration, urbanization

\begin{abstract}
ABSTRAK
Kemiskinan di kawasan transisi perdesaan ke perkotaan memiliki beberapa karakteristik yang berbeda dengan kemiskinan di perkotaan ataupun perdesaan. Fenomena ini juga terjadi di Kabupaten Sragen sebagai bagian dari kawasan peri-urban Solo Raya. Analisis deskriptif yang didasarkan pada penilaian kemiskinan partisipatif digunakan pada penelitian ini untuk memahami kondisi rumah tangga (RT) miskin pada kawasan transisi. Serangkaian pertanyaan diberikan kepada 100 RT miskin pada kawasan aglomerasi Sragen. Hasil penelitian menunjukkan bahwa 29 RT miskin menilai bahwa mereka memiliki penghidupan yang lebih baik dibandingkan dengan sepuluh tahun lalu, walaupun beberapa perubahan ini tidak berjalan seperti yang diharapkan. Ketidakmerataan distribusi dan perbedaan aksesibilitas di antara kelompok masyarakat terhadap akses kepada fasilitas perkotaan teridentifikasi sebagai persoalan umum, beserta rendahnya standar prasarana perkotaan di beberapa lingkungan permukiman mendorong memerlukan adanya perbaikan. Sementara itu, peningkatan kesempatan kerja tidak secara signifikan diiringi dengan
\end{abstract}


perubahan pekerjaan dari rumah tangga miskin yang diakibatkan oleh keterbatasan kompetensi dan kemampuan yang dimiliki. Pada konteks ini, kebijakan perkotaan di kawasan seperti itu tidak cukup hanya berkaitan dengan penyediaan dan perbaikan sarana dan prasarana perkotaan serta perbaikan kualitas lingkungan kehidupan, tetapi juga memerlukan adanya elemen-elemen kebijakan yang berfokus pada kebijakan pengembangan ketenagakerjaan, termasuk peningkatan kompetensi dan pemanfaatan aset untuk pengembangan usaha. Kebijakan-kebijakan ini dibutuhkan untuk meningkatkan kualitas dari lingkungan tanpa mengabaikan kemampuan rumah tangga miskin untuk turut mampu berkompetisi pada kawasan transisi perdesaan ke perkotaan.

Kata kunci: aglomerasi Sragen, kemiskinan, penilaian kemiskinan partisipatif, transisi perdesaan ke perkotaaan, urbanisasi

\section{PENDAHULUAN}

Pada beberapa dekade terakhir ini, urbanisasi di negara berkembang terjadi begitu cepat dan mencapai kondisi yang belum pernah terjadi sebelumnya. UNFPA (2007) memprediksi bahwa antara tahun 2020 sampai 2030 akan terjadi peningkatan dua kali lipat penduduk perkotaan terutama di Asia dan Afrika. Salah satu karakter utama dari urbanisasi yang terjadi pada beberapa dekade terakhir adalah bahwa mayoritas pertumbuhan perkotaan saat ini tidak terjadi pada kota-kota besar, melainkan terjadi pada kota sekunder dan kota kecil (Cohen, 2004; UNFPA, 2007; Rodríguez-Pose dan Hardy, 2015). Dalam konteks ini, proses urbanisasi tidak hanya terjadi pada kota-kota besar saja, tetapi terjadi juga pada kawasan-kawasan perdesaan yang mengalami proses transformasi spasial untuk menjadi perkotaan yang dikategorikan sebagai kawasan transisi.

Beberapa penelitian memperlihatkan bahwa transisi perdesaan ke perkotaan di negara berkembang tidak berjalan sesuai dengan harapan dan memunculkan tantangan yang salah satunya mencakup isu kemiskinan. Kemiskinan yang terjadi di daerah transisi perdesaan ke perkotaan memiliki karakteristik yang berbeda dengan kemiskinan di perkotaan ataupun perdesaan. Pada dasarnya kemiskinan merupakan fenomena yang kompleks, bersifat multidimensi dan tidak dapat dilihat hanya dari suatu angka absolut. Sejalan dengan hal tersebut, pandangan mengenai standar kemiskinan juga beragam, termasuk persepsi dan pendapat masyarakat miskin itu sendiri. Pandangan ini didasarkan pada realitas yang dialami penduduk miskin yang sangat lokal, kompleks, beragam dan dinamis (Chambers dan Conway, 1991). Padahal, ukuran-ukuran kemiskinan selama ini menitikberatkan pada konsumsi yang rendah atau pendapatan yang rendah sebagai dasar penetapan garis kemiskinan yang seragam. Analisis kritis terhadap diri sendiri, laporan penilaian diri dan metode partisipatif dapat menjadi kontribusi dalam pemahaman nilai, prioritas, dan preferensi penduduk miskin sehingga kita dapat mengetahui pandangan mereka tentang dirinya sendiri (Chambers, 2006). Terdapat berbagai cara dalam menilai atau mengukur kemiskinan, salah satunya melaui PPA (Participatory Poverty Assessment) yang menekankan pada pelibatan secara langsung penduduk miskin (Norton et al., 2001). Model penelitian kemiskinan dinamis seperti inilah yang diperlukan dalam memahami kemiskinan pada kawasan transisi perdesaan ke perkotaan yang berbeda dari kawasan perdesaan maupun perkotaan pada umumnya.

Sebagai bagian dari kawasan peri-urban dari Metropolitan Solo Raya, Kabupaten Sragen juga mengalami proses perkembangan dan perubahan kawasan perkotaan yang cukup pesat. Berdasarkan analisis yang dilakukan terhadap data potensi desa, terdapat peningkatan jumlah desa yang dikategorikan sebagai desa perkotaan dari hanya sepuluh desa di tahun 2000 menjadi 49 desa di tahun 2011 di Kabupaten Sragen. Perubahan terbesar terjadi pada desa-desa yang berada pada Kecamatan 
Sragen dan sekitarnya. Salah satu karakteristik utama yang dimiliki oleh kawasan-kawasan perkotaan yang berkembang di Kabupaten Sragen, apabila dibandingkan dengan yang terdapat di kabupaten-kabupaten lainnya di kawasan peri-urban Metropolitan Solo Raya, adalah masih kuatnya aktivitas pertanian yang berlangsung pada kawasan-kawasan perkotaan tersebut.

Dalam prosesnya, perubahan-perubahan tersebut tidak hanya terjadi secara fisik atau lingkungan spasial dari lingkungan perdesaan ke lingkungan perkotaan, tetapi juga termasuk perubahan kesempatan-kesempatan seperti kesempatan/peluang kerja dari kegiatan pertanian kepada kegiatan non pertanian. Perubahan-perubahan inilah yang mendorong munculnya perubahan karakteristik kemiskinan di kawasan transisi perdesaan ke perkotaan, dan meningkatkan jumlah rumah tangga miskin perkotaan di Kabupaten Sragen. Pada Kabupaten Sragen, aglomerasi Sragen yang terbentuk dari desa-desa perkotaan pada Kecamatan Sragen dan sekitarnya merupakan aglomerasi perkotaan terbesar dan paling cepat berkembang di Kabupaten Sragen dengan tingkat pertambahan jumlah kemiskinan di kawasan transisi perdesaan ke perkotaan sebesar $142 \%$.

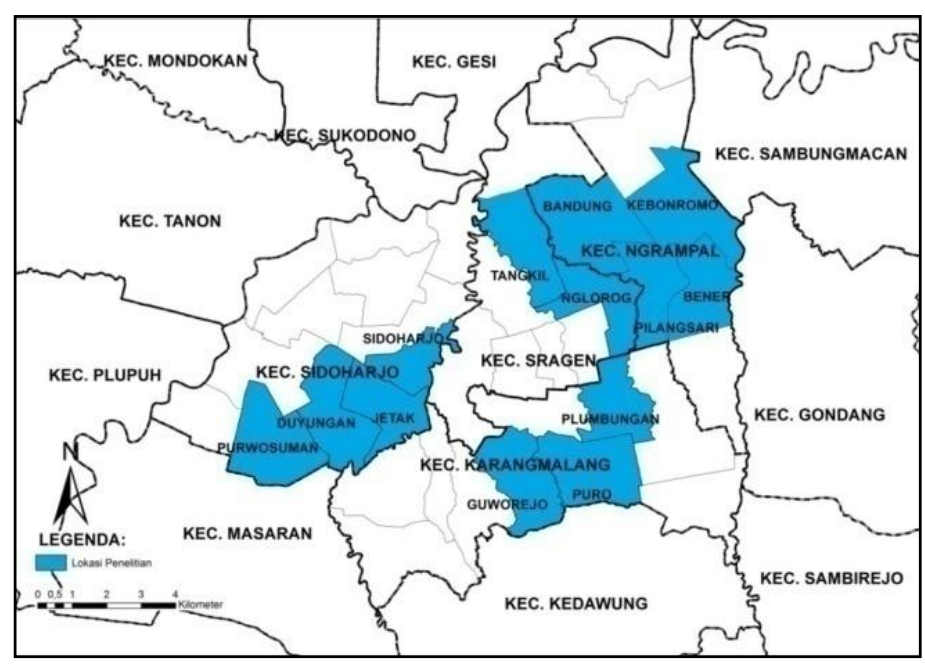

Gambar 1. Peta lokasi penelitian di aglomerasi Sragen

Sumber: Bappeda Kabupaten Sragen; BPS, 2011.

Berdasarkan pada permasalahan tersebut, penelitian ini ditujukan untuk menjawab pertanyaan "Seperti apakah kondisi rumah tangga miskin pada kawasan transisi perdesaan ke perkotaan di Kabupaten Sragen berdasarkan penilaian kemiskinan partisipatif?". Objek dari studi ini adalah rumah tangga miskin yang bermukim dan beraktivitas di kawasan transisi. Adapun wilayah studi pada penelitian ini berupa kawasan yang tersusun dari desa-desa yang mengalami perubahan kategori dari desa non-perkotaan berdasarkan pengkategorian yang dilakukan oleh BPS di tahun 2000 menjadi desa-desa yang dikategorikan sebagai desa-desa perkotaan di tahun 2011.

Bagian pertama studi ini akan membahas mengenai kajian literatur urbanisasi, kemiskinan, dan penilaian kemiskinan partisipatif. Dilanjutkan pada bagian kedua berupa gambaran singkat perubahan perkotaan dan kemiskinan di Kabupaten Sragen dan bagian ketiga yang membahas metode penelitian yang digunakan. Hasil temuan studi mengenai penilaian kemiskinan partisipatif pada kawasan transisi perdesaan ke perkotaan dibahas pada bagian keempat. Hasil dari identifikasi perubahan tersebut akan bermanfaat bagi perumusan kebijakan pengentasan kemiskinan yang lebih efektif menurut kondisi lingkungan dan kondisi kemiskinan yang dirasakan rumah tangga miskin itu sendiri yang tercantum pada bagian terakhir. 


\section{Urbanisasi dan Kemiskinan}

Proses urbanisasi dan metropolitanisasi saat ini telah meluas hingga jauh dari pusat kota dan membentuk kawasan peri-urban di pinggiran kawasan metropolitan, sebagai suatu kawasan tempat terjadinya campuran kegiatan dari perkembangan aktivitas perkotaan pada kawasan-kawasan pinggiran yang masih memiliki karakteristik non-perkotaan yang diindikasikan oleh masih besarnya aktivitas pertanian pedesaan di kawasan-kawasan itu. Wilayah peri-urban merupakan wilayah yang sangat dinamis yang dipengaruhi faktor pendorong dan penarik perubahan penduduk perkotaan dan fungsi kekotaan. Perubahanperubahan inilah yang disebut oleh Yunus (2008) sebagai transformasi wilayah. Berbagai penelitian dan informasi menunjukkan bahwa urbanisasi memberikan implikasi pada berbagai sektor kehidupan di antaranya sektor ekonomi, pendidikan, lingkungan, dan tata guna lahan (Bintarto, 1984).

Dalam proses urbanisasi, terutama pada negara-negara berkembang, kemiskinan merupakan salah satu karakteristik dan permasalahan yang juga memunculkan berbagai tantangan lain (Christiansen dan Todo 2014; Sridhar, 2015; Ravallion et al., 2008). Kemiskinan pada dasarnya tidak hanya berhubungan dengan dimensi pendapatan saja tetapi juga pada dimensi-dimensi lain nonpendapatan (Rahman et al., 2013). Umumnya, penduduk miskin pedesaan memiliki penghasilan yang berasal dari lebih dari satu sumber mata pencaharian, di samping juga berasal dari aset yang menghasilkan sumber makanan (Chambers dan Conway, 1991). Karakteristik ini memberikan perbedaan antara karakteristik kemiskinan perdesaan dengan kemiskinan perkotaan yang kemudian memunculkan perdebatan (Amis, 1995; Wratten, 1995; Engwall et al., 2007; Khan, 2000).

Perubahan-perubahan yang dialami orang yang hidup dalam kemiskinan menjadikan pemahaman tentang kemiskinan dan orang-orang yang hidup dalam kemiskinan sangat penting (Chambers, 2006). Analisis kritis terhadap diri sendiri, laporan penilaian diri dan metode partisipatif dapat menjadi kontribusi dalam pemahaman nilai, prioritas, dan preferensi penduduk miskin sehingga kita dapat mengetahui pandangan mereka tentang dirinya sendiri. (Chambers, 2006). Terdapat berbagai cara dalam menilai atau mengukur kemiskinan, salah satuya melaui Participatory Poverty Assessment (PPA) yang diperkenalkan oleh World Bank yang diadopsi dari konsep Participatory Rural Appraisal (PRA) (Norton et al., 2001). PPA atau Penilaian Kemiskinan Partisipatif menekankan pada pelibatan secara langsung penduduk miskin di dalam melakukan penilaian kepada kemiskinannya. Pendekatan partisipatif kemiskinan sangat bergantung pada persepsi komunitas terhadap kemiskinan dalam level rumah tangga. Keseluruhan persepsi terkait status kemiskinan rumah tangga di dalam suatu komunitas ini kemudian dinilai dan dipahami perubahannya dari waktu ke waktu (Rahman et al., 2013).

Melalui pelibatan rumah tangga miskin secara langsung, pendekatan penilaian kemiskinan partisipatif dapat memberikan gambaran pemahaman masyarakat miskin tentang kemiskinan dan perampasan hak; kendala dalam mengakses layanan publik dan jasa; serta prioritas masyarakat miskin dalam rumusan kebijakan publik (Norton et al., 2001). Pada perkembangannya, perbedaan karakteristik kemiskinan sudah seharusnya menjadi landasan perumusan kebijakan untuk pertumbuhan ekonomi dan pengentasan kemiskinan (Khan, 2000; Wallenborn, 2009; Ansoms dan Mckay 2010; Dutta dan Kumar, 2013). Penggunaan PPA diharapkan mampu meningkatkan efektivitas rumusan kebijakan publik (Norton et al., 2001). Sementara itu, fokus kebijakan pun sudah sepatutnya bergeser pada pembahasan bagaimana mengelola kawasan perkotaan (Ramachandran, 2014; Sugiri, 2009).

\section{Perkembangan Kawasan Perkotaan dan Kemiskinan di Kabupaten Sragen}

Kabupaten Sragen merupakan salah satu kabupaten yang berada di pinggiran 
Metropolitan Solo Raya, yang dibentuk oleh Kota Surakarta sebagai kawasan pusat, dan beberapa kabupaten lain seperti Kabupaten Boyolali, Klaten, Sukoharjo, Karanganyar dan Sragen sebagai kawasan pinggirannya. Sebagai kawasan yang berada di pinggiran kawasan metropolitan seperti ini, Kabupaten Sragen juga mengalami proses urbanisasi dalam arti perkembangan kawasan, penduduk dan aktivitas perkotaan di dalam wilayahnya. Berkembangnya aktivitas industri besar pada beberapa kawasan di sepanjang jalur jalan regional yang menghubungkan Kota Surakarta dengan Kota Sragen dan menuju ke kota-kota lain di Provinsi Jawa Timur memperlihatkan adanya pengaruh eksternal kepada perkembangan kawasan dan aktivitas perkotaan pada kabupaten ini. Di samping itu, perkembangan aktivitas permukiman, terutama di kawasan-kawasan perkotaan yang sudah terbentuk sebelumnya seperti di aglomerasi
Sragen mengindikasikan besarnya peranan internal dalam perkembangan aktivitas, kawasan dan penduduk perkotaan di Kabupaten Sragen.

Proses urbanisasi yang berlangsung di Kabupaten Sragen memperlihatkan telah terjadinya perkembangan kawasan perkotaan yang cukup pesat, terutama di sekitar ibukota Kabupaten Sragen. Perkembangan ini juga ditandai dengan perubahan kategori desa dari desa-desa non perkotaan di tahun 2000 menjadi desa-desa perkotaan di tahun 2011, pada desadesa yang terdapat di Kabupaten Sragen, ketika perubahan terbesar terjadi pada aglomerasi Sragen. Secara spasial di tahun 2000 terdapat empat pemusatan aktivitas perkotaan di Kabupaten Sragen dengan sepuluh desa perkotaan, yang berkembang dengan penambahan desa perkotaan yang cukup signifikan menjadi 49 desa perkotaan di tahun 2011 [lihat Gambar 2].

(a)

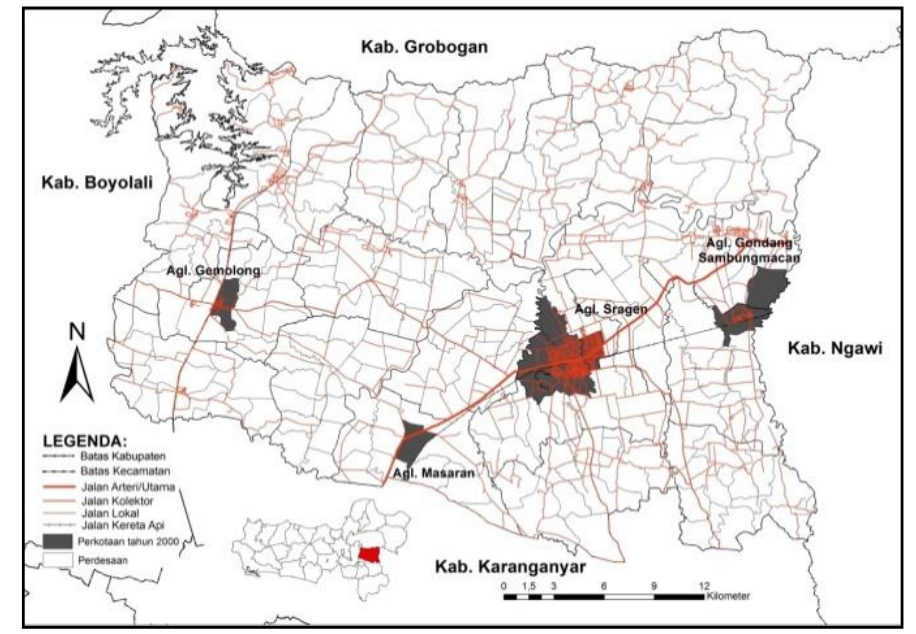

(b)

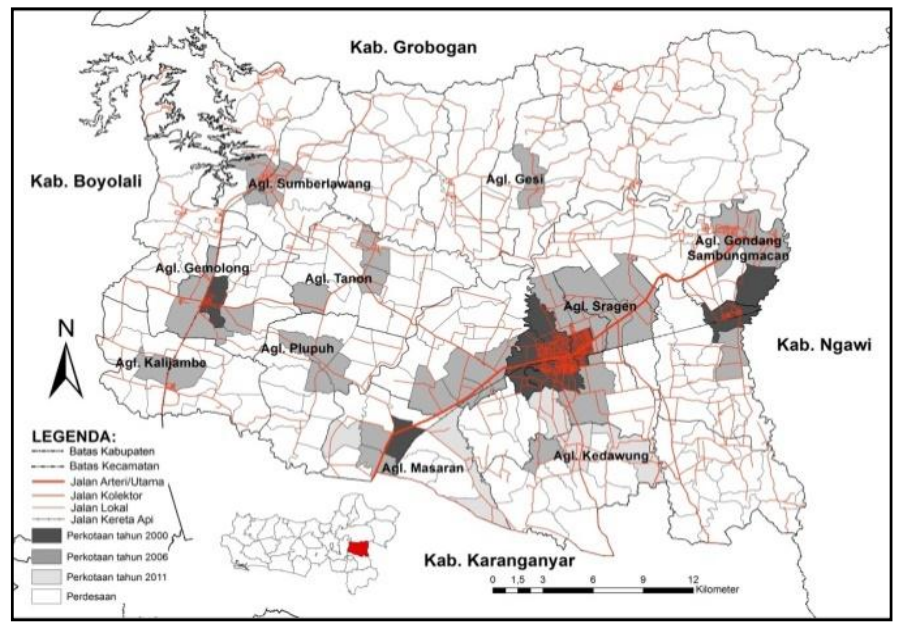

Gambar 2. Peta kawasan perkotaan (a) Tahun 2000; (b) Tahun 2011 Sumber: Hasil analisis dari data Potensi Desa BPS, 2000 dan 2011. 
Hal ini didorong oleh banyaknya desa yang mengalami perubahan kategori dari desa non perkotaan di tahun 2000 menjadi desa perkotaan di tahun 2010.

Analisis perubahan klasifikasi desa pedesaan (non perkotaan) menjadi desa perkotaan ini didasarkan kepada hasil pengklasifikasian desa-desa yang dilakukan oleh BPS terhadap data potensi desa yang dihasilkan, pada tahun 2000 dan 2011. BPS menggunakan kombinasi dari tiga buah variabel dalam melakukan pengklasifikasian seluruh desa di Indonesia ke dalam kategori desa perkotaan dan kategori desa non perkotaan. Ketiga buah variabel tersebut adalah tingkat kepadatan penduduk desa per kilometer persegi, persentase keluarga yang bekerja di sektor pertanian, dan ketersediaan/keberadaan fasilitas perkotaan. Berkembangnya desa-desa perkotaan baru ini menjadi faktor utama dalam meningkatkan kemiskinan perkotaan di Kabupaten Sragen ada di suatu desa yang dianalisis (Jones dan Mulyana, 2015).

Berubahnya klasifikasi beberapa desa perdesaan menjadi desa perkotaan, juga disertai dengan perubahan klasifikasi penduduk dan penduduk miskin yang tinggal di desa-desa tersebut, dari klasifikasi penduduk dan kemiskinan perdesaan menjadi klasifikasi penduduk dan kemiskinan perkotaan. Penduduk dan rumah tangga miskin yang sebelumnya menempati ruang-ruang perdesaan pun harus menyesuaikan pola hidup dan penghidupannya sesuai dengan perubahan lingkungan yang terjadi menjadi lingkungan perkotaan.

Tabel 1. Perubahan kemiskinan perkotaan dan perdesaan

\begin{tabular}{|c|c|c|c|c|c|c|c|c|}
\hline \multirow{3}{*}{ Aglomerasi Perkotaan } & \multicolumn{6}{|c|}{ Perkotaan } & \multirow{2}{*}{\multicolumn{2}{|c|}{$\begin{array}{c}\text { Perdesaan } \\
\text { Jumlah Rumah } \\
\text { Tangga Miskin }\end{array}$}} \\
\hline & \multicolumn{2}{|c|}{$\begin{array}{l}\text { Jumlah Rumah } \\
\text { Tangga Miskin }\end{array}$} & \multicolumn{4}{|c|}{ Peningkatan } & & \\
\hline & 2000 & 2011 & U-U & $\%$ & R-U & $\%$ & 2000 & 2011 \\
\hline Sragen & 4,280 & 7,968 & $-1,556$ & -42 & 5,244 & 142 & 17,846 & 7,882 \\
\hline Masaran & 659 & 3,087 & -78 & -3 & 2,506 & 103 & 7,309 & 3,543 \\
\hline Gondang-Sambungmacan & 1,299 & 2,861 & -402 & -26 & 1,964 & 126 & 12,560 & 6,062 \\
\hline Gemolong & 683 & 2,615 & 52 & 3 & 1,880 & 97 & 6,851 & 2,912 \\
\hline Kalijambe & 0 & 809 & 0 & 0 & 809 & 100 & 8,750 & 5,400 \\
\hline Tanon & 0 & 1,307 & 0 & 0 & 1,307 & 100 & 12,169 & 6,032 \\
\hline Kedawung & 0 & 1,282 & 0 & 0 & 1,282 & 100 & 6,999 & 2,962 \\
\hline Sumberlawang & 0 & 1,142 & 0 & 0 & 1,142 & 100 & 9,111 & 6,164 \\
\hline Plupuh & 0 & 1,120 & 0 & 0 & 1,120 & 100 & 9,048 & 4,354 \\
\hline Gesi & 0 & 288 & 0 & 0 & 288 & 100 & 3,407 & 2,409 \\
\hline Total & 6,921 & 22,479 & $-1,984$ & & 17,542 & & 94,050 & 47,720 \\
\hline
\end{tabular}

*Keterangan:

Aglomerasi Perkotaan: kumpulan desa-desa perkotaan yang terbentuk di tahun 2011

U-U: urban to urban, yaitu desa-desa yang tetap terklasifikasi sebagai desa-desa perkotaan di kedua titik waktu

R-U: rural to urban, yaitu dari desa-desa yang mengalami perubahan dari desa rural menjadi desa urban

Sumber: BPS 2000; TNP2K, 2011.

Tabel 1 menunjukkan perubahan besaran kemiskinan perkotaan yang telah ada sejak tahun 2000 dan kawasan perkotaan baru di tahun 2011.

Tabel tersebut menunjukkan adanya peningkatan proporsi kemiskinan perkotaan di desa-desa perkotaan baru yang diklasifikasikan sebagai desa R-U.

\section{METODOLOGI}

Metodologi yang digunakan dalam penelitian "Penilaian Kemiskinan Partisipatif pada Kawasan Transisi Perdesaan ke Perkotaan di Kabupaten Sragen" ini adalah metode penelitian deskriptif. Penelitian ini menggunakan pendekatan campuran yang bertujuan mendapatkan gambaran dari penilaian kemiskinan partisipatif pada 100 
responden rumah tangga miskin yang bertempat tinggal dan beraktivitas di kawasan transisi perdesaan ke perkotaan di aglomerasi Sragen. Penggunaan kuesioner terbuka bertujuan mengidentifikasi penilaian kemiskinan partisipatif, ketika data mengenai kemiskinan yang tersedia selama ini hanya menunjukkan kemiskinan secara statis. Melalui wawancara langsung dengan responden, dapat diketahui proses perubahan yang terjadi dan bagaimana pandangan rumah tangga terhadap perubahan karakteristik kemiskinanan yang dialaminya. Hasil dari identifikasi perubahan tersebut akan bermanfaat bagi perumusan kebijakan pengentasan kemiskinan yang lebih efektif menurut kondisi lingkungan dan kondisi kemiskinan yang dirasakan rumah tangga miskin itu sendiri.

Tabel 2. Pembagian sampel

\begin{tabular}{clrr}
\hline No. & Nama Desa & Jumlah RT Miskin R-U & Jumlah Sampel \\
\hline 1 & Nglorog & 257 & 5 \\
2 & Tangkil & 293 & 5 \\
3 & Pilangsari & 503 & 8 \\
4 & Bener & 437 & 10 \\
5 & Kebonromo & 641 & 10 \\
6 & Bandung & 456 & 12 \\
7 & Guworejo & 459 & 8 \\
8 & Puro & 459 & 8 \\
9 & Plumbungan & 7 \\
10 & Purwosuman & 320 & 8 \\
11 & Duyungan & 446 & 8 \\
12 & Jetak & 353 & 5 \\
13 & Sidoharjo & 353 & 6 \\
\hline
\end{tabular}

Sumber: Hasil analisis (2016).

\section{HASIL DAN PEMBAHASAN}

\section{Karakteristik Demografi Rumah Tangga Miskin}

Perbedaan karakteristik antara kawasan transisi dari perdesaan ke perkotaan dengan kawasan perdesaan dan kawasan perkotaan tidak hanya terjadi secara fisik lingkungan, tetapi juga mendorong perbedaan karakteristik penduduk dan aktivitas di dalamnya. Dapat dikatakan bahwa karakteristik demografi rumah tangga miskin yang ada tergolong cukup baik dan memiliki potensi untuk berproduksi. Hal ini ditunjukkan dengan mayoritas anggota dan kepala keluarga pada rumah tangga miskin berada pada usia produktif (usia 15 sampai 64). Hasil survei lapangan menunjukkan bahwa perbandingan antara anggota rumah tangga yang bekerja dan tidak bekerja adalah sebesar $47.51 \%$ atau dengan kata lain setiap rumah tangga memiliki satu hingga dua anggota yang bekerja. Keberadaan penduduk usia produktif tentu memberikan peluang peningkatan kesejahteraan dengan potensinya sebagai aktor penggerak ekonomi rumah tangga. Rata-rata jumlah anggota keluarga pada rumah tangga miskin adalah sebesar 3.91 jiwa atau dengan kata lain adalah rasio ketergantungan yang cukup berimbang. Namun pengalaman dan kemampuan bekerja dari sebagian besar anggota dan kepala keluarga yang relatif terbatas pada aktivitas pertanian tradisional memberikan keterbatasan kemampuan dari para rumah tangga miskin dalam melakukan peningkatan kesejahteraan keluarganya.

\section{Perubahan Karakteristik Lingkungan Rumah Tangga Miskin}

Perkembangan kawasan perkotaan ditandai dengan perubahan lingkungan perkotaan itu sendiri. Perubahan-perubahan tersebut termasuk di dalamnya terkait sarana fasilitas sosial, infrastruktur, lapangan pekerjaan hingga hal-hal yang berkaitan dengan kondisi sosial masyarakat dan pencemaran lingkungan permukiman. 
Tabel 3. Jarak ke fasilitas kesehatan

\begin{tabular}{|c|c|c|c|c|c|c|}
\hline & \multicolumn{5}{|c|}{2016} & \multirow[b]{2}{*}{ Total } \\
\hline & $\begin{array}{l}<0.5 \\
\text { km }\end{array}$ & $\begin{array}{c}0.5-1 \\
\text { km }\end{array}$ & $\begin{array}{c}1-1.5 \\
\text { km }\end{array}$ & $\begin{array}{c}1.5-2 \\
\text { km }\end{array}$ & $\begin{array}{l}>2 \\
\mathbf{k m}\end{array}$ & \\
\hline \multirow{6}{*}{ 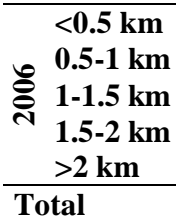 } & 19 & 0 & 0 & 0 & 0 & 19 \\
\hline & 5 & 29 & 0 & 0 & 0 & 34 \\
\hline & 0 & 0 & 11 & 0 & 0 & 11 \\
\hline & 0 & 1 & 1 & 10 & 0 & 12 \\
\hline & 6 & 2 & 2 & 0 & 14 & 24 \\
\hline & 30 & 32 & 14 & 10 & 14 & 100 \\
\hline
\end{tabular}

Sumber: Hasil analisis, 2016.

Pada perkembangan sepuluh tahun antara tahun 2006 hingga 2016, telah terjadi beberapa perubahan di aglomerasi Sragen. Perkembangan penyediaan fasilitas kesehatan menjadikannya menjadi fasilitas yang semakin mudah dijangkau dilihat dari jarak yang relatif mengecil, terutama pada rentang jarak di atas 2 $\mathrm{km}$ yang menurun dari 24 kasus (responden) di tahun 2006 menurun menjadi hanya 14 kasus (responden) saat ini.

Perbaikan kondisi yang terjadi pada akses masyarakat kepada fasilitas kesehatan ini diakibatkan oleh dibangunnya beberapa praktik bidan dan praktik dokter baru, serta dibangunnya rumah sakit baru. Akan tetapi, perbaikan serupa tidak ditemui pada penyediaan fasilitas pendidikan dan juga fasilitas perdagangan.

Berdasarkan fakta ini, dapat ditarik kesimpulan bahwa kemudahan akses dan penyediaan fasilitas yang ditawarkan oleh proses urbanisasi tidak ditemui pada semua jenis fasilitas atau hanya ditemui pada jenisjenis fasilitas tertentu.

Sementara itu terkait dengan kondisi infrastruktur, kondisi pencemaran lingkungan, dan kondisi sosial masyarakat, mayoritas rumah tangga menganggap bahwa pada lingkungan permukiman mereka saat ini cenderung lebih baik dari sepuluh tahun yang lalu. Secara keseluruhan, hampir seluruh aspek pada karakteristik lingkungan rumah tangga miskin mendukung penghidupan yang lebih baik dan peningkatan kesejahteraan bagi rumah tangga miskin [lihat Gambar 3].

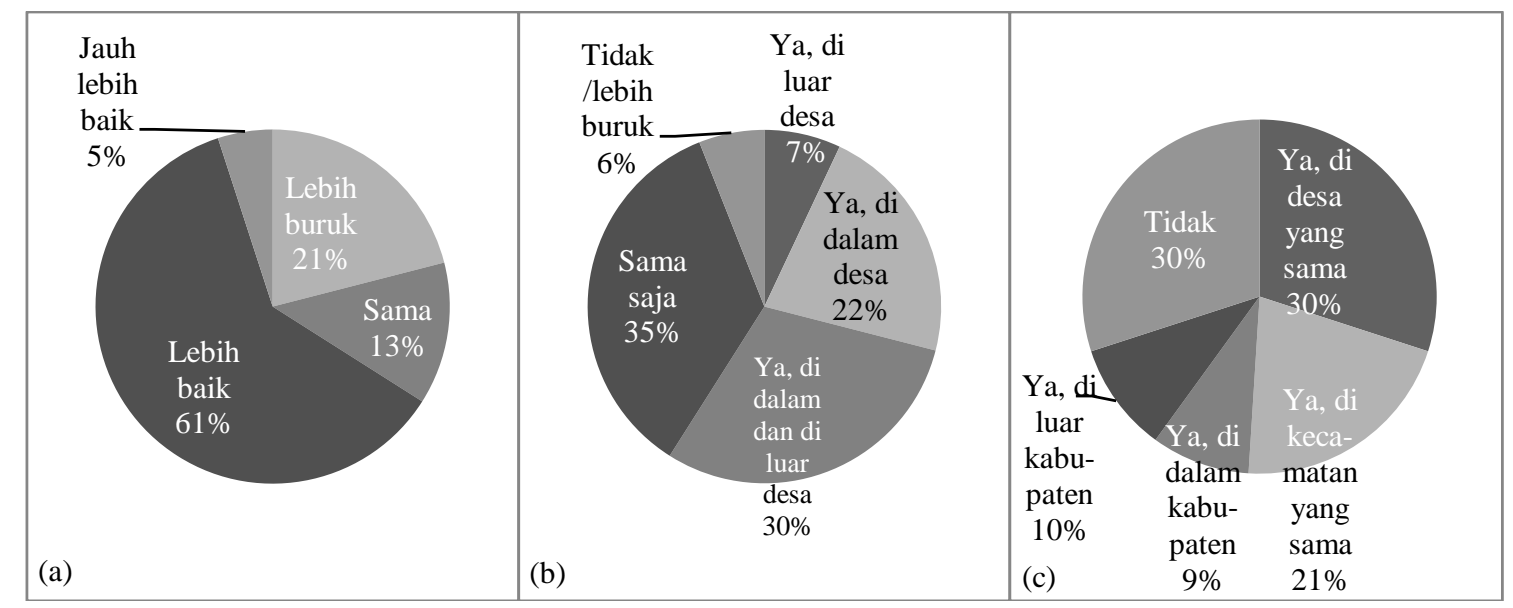

Gambar 3. (a) Kesempatan kerja rumah tangga; (b) Perluasan kegiatan usaha rumah tangga;

(c) Perubahan lokasi kerja rumah tangga

Sumber: Hasil analisis (2016).

Pada dasarnya, proses urbanisasi yang terjadi di Kabupaten Sragen juga mendorong muncul dan berkembangnya peluang serta kesempatan di luar sektor pertanian. Mayoritas rumah tangga miskin menganggap kesempatan kerja lebih baik dari sepuluh tahun yang lalu. Kesempatan kerja yang semakin terbuka ini mendorong perubahan lokasi kerja beberapa rumah tangga baik yang masih di desa yang sama hingga keluar Kabupaten Sragen. Akan tetapi tidak terlalu banyak masyarakat yang mengalami perluasan kerja (baik di dalam desa dan luar desa maupun keduanya). Sebesar 35\% rumah tangga miskin tidak mengalami perluasan lapangan kerja. Hal ini menunjukkan bahwa rumah tangga miskin yang mengalami perluasan kegiatan usaha tidak meningkat secara signifikan meski telah terbukanya peluang ekonomi dari proses urbanisasi. Padahal seharusnya proses urbanisasi juga 
dapat dimanfaatkan untuk melakukan perluasan lapangan kerja sehingga mendorong penghidupan yang lebih baik.

\section{Perubahan Karakteristik Penghidupan Rumah Tangga Miskin}

Penghidupan rumah tangga miskin bergantung pada beberapa faktor dan tidak hanya bergantung pada mata pencaharian, meski faktor pekerjaan sangatlah penting bagi rumah tangga miskin. Peningkatan kualitas fasilitas tempat tinggal seperti akses air bersih dan sanitasi sangat penting dalam program pengentasan kemiskinan, dan perubahannya akan menggambarkan peningkatan kesejahteraan rumah tangga jangka panjang.

Tabel 4. Sumber air bersih rumah tangga

\begin{tabular}{|c|c|c|c|c|}
\hline & \multicolumn{3}{|c|}{2016} & \multirow[t]{2}{*}{ Total } \\
\hline & Sumur & PDAM & Lainnya & \\
\hline Sumur & 58 & 10 & 12 & 80 \\
\hline PDAM & 0 & 14 & 1 & 15 \\
\hline Lainnya & 1 & 1 & 3 & 5 \\
\hline Total & 59 & 25 & 16 & 100 \\
\hline
\end{tabular}

Sumber: Hasil analisis, 2016.

Tabel 4 memperlihatkan bahwa proses urbanisasi yang terjadi cukup mempengaruhi kualitas penyediaan air bersih rumah tangga miskin khususnya di kawasan transisi. Fakta di lapangan menunjukkan cukup besarnya penurunan penggunaan sumur sebagai sumber kebutuhan air minum yang kemudian beralih menjadi PDAM atau sumber lain yang sebagian besar berupa penyediaan air secara komunal dan mandiri.

Selain itu, kesadaran masyarakat dalam pengelolaan limbah tinja juga relatif meningkat. Kondisi ini diperlihatan oleh angka kepemilikan septic tank pada keluarga-keluarga miskin yang diamati yang meningkat dari $75 \%$ menjadi $92 \%$ dalam sepuluh tahun ini [lihat Tabel 5].

Tabel 5. Kepemilikan sanitasi rumah tangga

\begin{tabular}{|c|c|c|c|c|c|}
\hline & \multicolumn{4}{|c|}{2016} & \multirow[t]{2}{*}{ Total } \\
\hline & $\begin{array}{c}\text { Tidak } \\
\text { ada }\end{array}$ & $\begin{array}{c}\text { Jamban } \\
\text { sungai }\end{array}$ & $\begin{array}{c}\text { Septic } \\
\text { tank }\end{array}$ & $\begin{array}{c}\text { Lain- } \\
\text { nya }\end{array}$ & \\
\hline $\begin{array}{l}\text { Tidak } \\
\text { ada }\end{array}$ & 4 & 0 & 6 & 0 & 10 \\
\hline ¿ Jamban & 0 & 3 & 10 & 0 & 13 \\
\hline $\begin{array}{c}\text { নิ Septic } \\
\text { tank }\end{array}$ & 0 & 0 & 75 & 0 & 75 \\
\hline $\begin{array}{l}\text { Lain- } \\
\text { nya }\end{array}$ & 0 & 0 & 1 & 1 & 2 \\
\hline Total & 4 & 3 & 92 & 1 & 100 \\
\hline
\end{tabular}

Salah satu karakter yang kuat di dalam karakteristik keluarga miskin di kawasan transisi adalah besarnya persentase keluarga miskin yang berkerja sebagai petani, baik pemilik lahan maupun buruh tani [lihat Tabel $6]$.

Tabel 6. Pekerjaan utama kepala keluarga

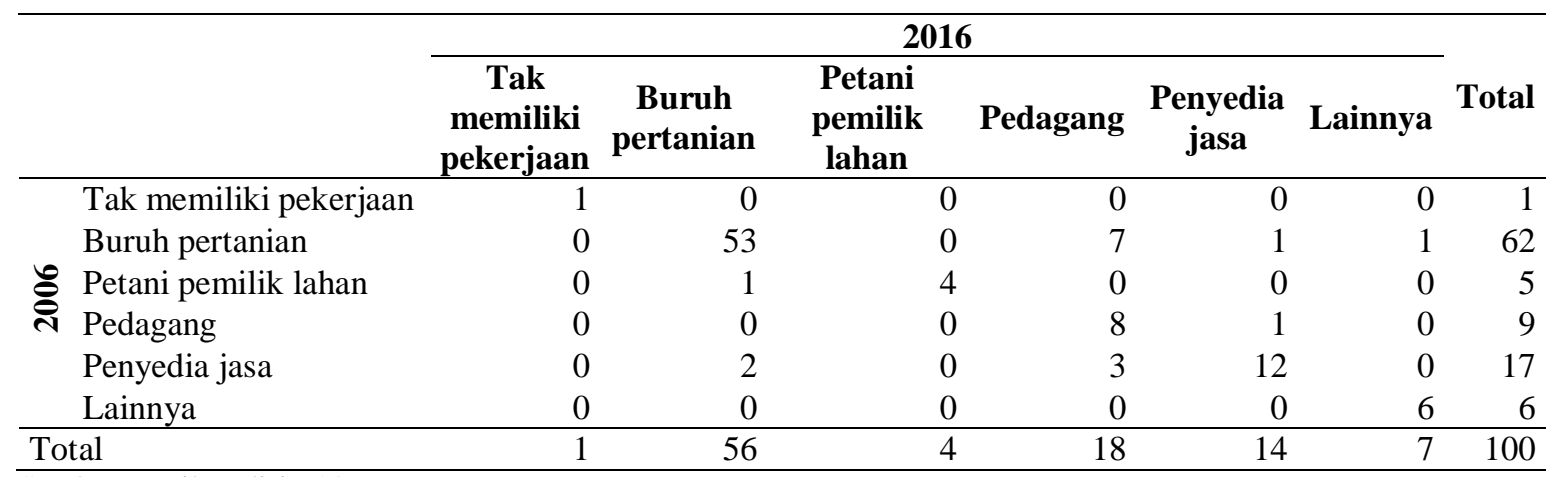

Sumber: Hasil analisis, 2016. 
Hal ini menunjukkan bahwa di dalam proses urbanisasi yang terjadi, mayoritas kepala keluarga masih bergantung pada sektor pertanian. Kondisi ini mengindikasikan besarnya keterikatan rumah tangga miskin terhadap kegiatan pertanian yang juga merupakan latar belakang kompetensi dan kemampuan yang dimiliki. Di sisi lain, proses urbanisasi yang terjadi turut memberi implikasi kepada pengurangan kesempatan kerja di sektor pertanian. Berdasarkan hasil survei lapangan, diketahui bahwa seorang petani pemilik lahan telah kehilangan lahannya, walau masih dapat bergerak di bidang pertanian sebagai buruh tani. Sementara itu, tujuh orang buruh pertanian berubah pekerjaan sebagai pedagang dan satu orang sebagai penyedia jasa.

Pada dasarnya proses urbanisasi yang terjadi di kawasan transisi mampu memperluas kesempatan kerja pada bidang-bidang lain pada sektor sekunder dan tersier, namun keterbatasan kapasitas dan kemampuan kerja di luar sektor pertanian menjadi penghambat peralihan mata pencaharian para tenaga kerja. Selama sepuluh tahun terakhir hanya terdapat 10 kepala keluarga yang beralih menjadi pedagang dari pekerjaan sebelumnya sebagai buruh pertanian dan penyedia jasa skala kecil, 2 orang lain beralih dari pedagang dan buruh tani menjadi penyedia jasa, dan 1 kepala keluarga memiliki pekerjaan lain sebagai PNS.

Kondisi ini menunjukkan bahwa perubahan lingkungan pada kawasan transisi perdesaan ke perkotaan tidak banyak diiringi oleh perubahan pekerjaan dari tenaga kerja secara signifikan. Kondisi seperti ini secara spesifik hanya dialami kawasan transisi perdesaan ke perkotaan yang berbeda dengan yang terjadi pada kawasan perdesaan maupun perkotaan pada umumnya. Besar kemungkinan hal ini dilandasi oleh kompetensi tenaga kerja yang tergolong rendah sehingga tidak bisa beradaptasi dan terserap pada pasar tenaga kerja. Ini diindikasikan dari rendahnya angka orang yang pernah terlibat mengikuti pelatihan keterampilan yang masih kurang dari $10 \%$. Dengan rendahnya kapasitas dan kemampuan yang ada, perubahan pekerjaan yang terjadi pun masih belum mampu mengubah kondisi kemiskinan yang dideritanya karena skala usaha yang dilakukan masih relatif kecil sehingga masih bisa digolongkan pada aktivitas yang tidak terlalu produktif dan sifatnya subsisten. Berdasarkan hal tersebut, perlu adanya kebijakan terkait peningkatan keterampilan agar tenaga kerja dapat beradaptasi dengan perubahan lingkungan yang terjadi pada kawasan transisi perdesaan ke perkotaan. Hal yang juga perlu mendapat perhatian di dalam kebijakan peningkatan keterampilan usaha ini adalah pengembangannya kepada para wanita atau ibu rumah tangga yang ada, karena banyaknya rumah tangga miskin yang tidak hanya memiliki satu sumber penghasilan. Selain sekitar 20\% kepala keluarga memiliki pekerjaan sampingan, $71 \%$ keluarga memiliki anggota keluarga lain yang bekerja untuk membantu penghidupan rumah tangga, dan umumnya adalah perempuan. Kesempatan kerja di sektor non pertanian dan kesempatan kerja bagi kaum wanita menjadi peluang yang muncul seiring dengan semakin berkembangnya proses urbanisasi yang terjadi di Kawasan Perkotaan Sragen.

Berkembangnya peluang dan kesempatan usaha pada keluarga miskin di kawasan transisi seperti ini juga diperlihatkan oleh besarnya kepemilikan aset lain di luar aset lahan pertanian. Aset lahan tetap merupakan aset terpenting dan pembeda kesejahteraan rumah tangga. Akan tetapi, bertambahnya dan berkembangnya jenis dan kepemilikan aset seperti kendaraan bermotor, hewan ternak, alatalat dan fasilitas usaha lain mengindikasikan adanya perkembangan kesempatan usaha yang dapat menjadi alat pendukung penghidupan rumah tangga miskin tersebut. 
Tabel 7. Kepemilikan aset rumah tangga

\begin{tabular}{lclc}
\hline \multicolumn{1}{c}{ Aset tahun 2006 } & \multicolumn{2}{c}{ Aset tahun 2016 } \\
\hline \multicolumn{1}{c}{ Variasi Jawaban } & Frekuensi & Motor & Frekuensi \\
\hline Motor & 20 & Kambing & 74 \\
Kambing & 8 & Sapi & 13 \\
Sapi & 7 & Alat usaha & 11 \\
Alat usaha & 1 & Tabungan & 3 \\
Tabungan & 2 & Pembibitan Lele & 2 \\
& & Sepeda & 2 \\
& & Total & 1 \\
\hline Total & 38 & & 106 \\
\hline
\end{tabular}

Sumber: Hasil Analisis (2016).

\section{Penilaian Rumah Tangga Miskin Terhadap Kemiskinan dan Kondisi Kemiskinan}

Untuk mengetahui dan memahami prioritas, opini, preferensi, pengalaman, dan rekomendasi kebijakan, rumah tangga miskin diminta memberikan pandangan dan penilaian yang berkaitan dengan kemiskinan dan kondisi dirinya dan keluarganya. Mayoritas responden berpendapat bahwa kemiskinan disebabkan oleh tidak adanya penghasilan (44.97\%). Di sisi lain, terdapat 29 rumah tangga miskin yang menyampaikan bahwa kemiskinan yang dialami adalah karena alasan ketidakberdayaan, 22 rumah tangga miskin lain menyatakan keterbatasan di dalam kepemilikan asetlah yang menjadi penyebab, sementara 20 rumah tangga miskin menyatakan penyebab kemsikinan dikarenakan kondisi rumah yang tidak layak. Hal ini mengindikasikan bahwa selain penghasilan kelurga yang merupakan aspek yang sangat penting, ketidakberdayaan masyarakat, ketiadaan aset dan kondisi rumah dan lingkungan yang layak juga merupakan hal-hal yang perlu diperhatikan di dalam persoalan kemiskinan dan kemampuan memenuhi kebutuhan sehari-hari pada kawasan transisi seperti yang terjadi di Kabupaten Sragen. Sementara itu, hal-hal lain seperti tingkat persaingan dan kemudahan dalam mengakses fasilitas-fasilitas umum bukan menjadi prioritas rumah tangga miskin dalam mengidentifikasi penyebab kemiskinan yang dialaminya.

Selain itu, penilaian partisipatif ini juga menemukan indikasi adanya perbaikan kehidupan dan penghidupan rumah tangga miskin sehingga menjadi lebih baik dari kondisi sebelumnya dan mampu keluar dari kemiskinan. Perbaikan-perbaikan dan kesempatan-kesempatan yang muncul akibat dari urbanisasi seperti kesempatan kerja, perbaikan fasilitas berkurangnya tanggungan keluarga, kepemilikan aset, perbaikan kondisi ekonomi, dan ikatan sosial antar warga mendorong peningkatan kesejahteraan rumah tangga miskin meski juga terdapat kekurangan seperti harga kebutuhan yang tinggi, sulitnya persaingan kerja, penghasilan yang tidak tetap, dan biaya pendidikan.

Secara keseluruhan, rumah tangga miskin menilai kondisi mereka saat ini sudah sedikit jauh lebih baik dari sepuluh tahun yang lalu dengan rata-rata penilaian pada angka 6.59 yang dalam skala Likert yang digunakan yang artinya lebih tinggi dari angka tengah 5 walau masih jauh dari nilai maksimal 9 (sangat/jauh lebih baik). Rumah tangga miskin juga lebih banyak menggambarkan kelebihan-kelebihan kondisi saat ini seperti kesempatan kerja yang lebih terbuka, fasilitas sudah lebih baik, dan perbaikan-perbaikan lain pada bidang sosial maupun ekonomi. 
Tabel 8. Penilaian rumah tangga terkait penyebab kemiskinan

\begin{tabular}{lrr}
\hline Variasi Jawaban & Frekuensi & $\begin{array}{c}\text { Persentase } \\
(\mathbf{\%})\end{array}$ \\
\hline Tidak memiliki & 67 & 44.97 \\
penghasilan & 29 & 19.46 \\
Tidak berdaya & 22 & 14.77 \\
Tidak memiliki aset & 20 & 13.42 \\
Rumah tidak layak & 3 & 2.01 \\
Tidak dapat bersaing & 3 & \\
Tidak dapat & 5 & 2.01 \\
mengakses fasilitas & $\mathbf{5}$ & $\mathbf{1 0 0}$ \\
Lainnya & \multicolumn{1}{c}{ Total } &
\end{tabular}

Sumber: Hasil analisis, 2016.

Tabel 9. Penilaian kondisi kemiskinan rumah tangga

\begin{tabular}{rlrrr}
\hline & & \multicolumn{2}{c}{$\mathbf{2 0 1 6}$} & \\
\cline { 3 - 4 } & \multicolumn{2}{c}{ Miskin } & $\begin{array}{c}\text { Tidak } \\
\text { miskin }\end{array}$ & Total \\
\hline 2006 & $\begin{array}{l}\text { Miskin } \\
\text { Tidak } \\
\text { miskin }\end{array}$ & 68 & 29 & 97 \\
\hline Total & 1 & 2 & 3 \\
\hline
\end{tabular}

Sumber: Hasil analisis, 2016.

\section{Implikasi Kebijakan untuk Pengentasan Kemiskinan pada Kawasan Transisi Perdesaan ke Perkotaan}

Berbagai penelitian dan informasi yang salah satunya dilakukan oleh Bintarto (1984) menunjukkan bahwa urbanisasi memberikan implikasi pada berbagai sektor kehidupan. Seperti yang disampaikan oleh McGee (1991) proses urbanisasi tidak hanya melakukan perubahan struktural secara fisik spasial, tetapi juga pada aspek-aspek lain seperti penduduk, ekonomi, cara hidup dan kesempatankesempatan dan hal ini juga terjadi pada aglomerasi Sragen yang dikategorikan sebagai suatu kawasan perkotaan kecil. Cohen (2004; 2006) berpendapat bahwa proses urbanisasi di kota-kota kecil dan menengah merupakan salah satu tantangan urbanisasi di masa depan. Proses urbanisasi ini juga memungkinkan terjadinya peningkatan kualitas hidup dan penghidupan melalui peningkatan kualitas lingkungan dan fasilitas pada tempat tinggal, sumber penghasilan yang semakin bervariasi, kesempatan-kesempatan yang berkembang, dan kepemilikan aset rumah tangga. Namun, beberapa perubahan tersebut ternyata belum mampu berjalan dan berdampak optimal, terutama bagi rumah tangga miskin, sehingga membutuhkan dukungan kebijakan untuk pengentasan kemiskinan tersebut.

Berdasarkan hasil analisis, diketahui bahwa salah satu karakter utama dari rumah tangga miskin di kawasan transisi adalah terbatasnya kapasitas dan kemampuan berusaha terutama di luar sektor pertanian. Keterbatasan aset usaha juga merupakan salah satu karakter penting yang dapat menghambat kelompok usia produktif dalam memanfaatkan perubahanperubahan lingkungan dan kesempatan akibat proses urbanisasi yang terjadi. Oleh karena itu, disamping kebijakan terkait ketersediaan dan perbaikan fasilitas sosial serta peningkatan lingkungan tempat tinggal, diperlukan juga adanya kebijakan yang mampu menyentuh aspek ketenagakerjaan dan kepemilikan aset untuk meningkatkan kemampuan usaha dari tenaga kerja.

Kebijakan ini dimaksudkan tidak hanya untuk menyiapkan dan merencanakan lingkungan yang dapat mendukung kesejahteraan, tetapi juga meningkatkan kemampuan rumah tangga miskin agar mampu beradaptasi terhadap perubahan serta kesempatan kerja yang ada. Tanpa adanya kebijakan terkait peningkatan kapasitas tenaga kerja dan kepemilikan aset, maka proses urbanisasi yang terjadi tidak akan memberikan pengaruh optimal dalam upaya pengentasan kemiskinan di kawasan transisi.

\section{KESIMPULAN DAN REKOMENDASI}

Studi yang dilakukan di aglomerasi Sragen ini menjelaskan bahwa penilaian kemiskinan partisipatif mampu memberikan perspektif yang lebih baik terhadap kondisi rumah tangga miskin daripada perhitunganperhitungan kemiskinan konvensional. Seperti yang telah dijelaskan oleh Norton et al. (2001), pendekatan penilaian kemiskinan partisipatif ini dapat memberikan gambaran pemahaman masyarakat miskin tentang kemiskinan dan 
kekurangan atau kehilangan haknya, kendala dalam mengakses layanan dan jasa publik, serta aspirasi ke dalam prioritas yang diinginkan masyarakat miskin di dalam rumusan kebijakan publik.

Hasil studi menunjukkan bahwa proses urbanisasi yang terjadi di Kabupaten Sragen telah mendorong perubahan-perubahan, lingkungan tempat tinggal, kehidupan dan penghidupan dari keluarga-keluarga miskin. Namun beberapa perubahan tersebut ternyata belum mampu berjalan dan berdampak optimal terutama bagi rumah tangga miskin. Permasalahan yang paling umum ditemui adalah kemudahan akses dan penyediaan fasilitas yang tidak merata, disamping dari kondisi lingkungan dan fasilitas tempat tinggal yang perlu diperbaiki. Selain itu diketahui bahwa perubahan-perubahan fisik dan lingkungan akibat terjadinya proses urbanisasi saat ini mampu memberi perluasan kesempatan kerja yang lebih terbuka, namun hal ini tidak serta merta diiringi dengan perubahan pekerjaan dari tenaga kerja secara signifikan. Kondisi ini disebabkan oleh kemampuan dan kompetensi tenaga kerja yang tergolong rendah dan masih terbatas pada kegiatan pertanian yang merupakan lingkungan aktivitasnya di masa lalu.

Berdasarkan hal ini, intervensi perlu dilakukan agar proses urbanisasi yang terjadi dapat turut meningkatkan kesejahteraan rumah tangga miskin di kawasan transisi. Implikasi kebijakan yang diperlukan merupakan suatu kebijakan yang terstruktur dalam mengarahkan dan membentuk lingkungan yang dapat mendukung kesejahteraan rumah tangga dan setiap individu yang ada, termasuk kebijakan peningkatan dan pengembangan kualitas sumber daya manusia untuk meningkatkan kemampuan adaptasi tenaga kerja di dalam perubahan-perubahan yang terjadi di lingkungan tempat tinggal dan tempatnya beraktivitas.

\section{DAFTAR PUSTAKA}

Amis, P. (1995). Making sense of urban poverty. Environment and Urbanization, 7 (1), 145158.

Ansoms, A., \& McKay, A. (2010). A quantitative analysis of poverty and livelihood profiles: The case of rural Rwanda. Food Policy, 35 (6), 584-598.

Bintarto. (1984). Urbanisasi dan Permasalahannya. Jakarta: Ghalia Indonesia.

Chambers, R. (2006). Poverty Unperceived: Traps, Biases and Agenda. Brighton.

Chambers, R., \& Conway, G. R. (1991). Sustainable rural livelihoods: practical concepts for the 21st Century.

Christiansen, L., \& Todo, Y. (2014). Poverty Reduction During the Rural-Urban Transformation-The Role of the Missing Middle. World Development, 63, 43-58.

Cohen, B. (2004). Urban growth in developing countries: A review of current trends and a caution regarding existing forecasts. World Development, 32 (1), 23-51.

Cohen, B. (2006). Urbanization in developing countries: Current trends, future projections , and key challenges for sustainability. Technology in Society, 28, 63-80.

Dutta, S., \& Kumar, L. (2013). Poverty Dynamics in Rural India: An Asset-Based Approach Swati Dutta. The Journal of Applied Economic Research, 7 (4), 475-506.

Engwall, A., Sjöberg, Ö., \& Sjöholm, F. (2007). Understanding Rural Poverty in Cambodia.

Jones, G., \& Mulyana, W. (2015). Urbanization in Indonesia. Jakarta.

Khan, M. H. (2000). Rural Poverty in Developing Countries.

McGee, T. G. (1991). The Emergence of Desa-Kota Regions in Asia: Expanding a Hypothesis. In Ginsburg, N., Koppeö, B., \& M. T. G., eds. The Extended Metropolis: Settlement Transition in Asia. Honolulu: University of Hawai Press.

Norton, A., Bird, B., Brock, K., Kakande, M., \& Turk, C. (2001). A rough guide to PPAs (Participatory Poverty Assessment): An introduction to theory and practice. London: Overseas Development Institute

Rahman, P. M. M., Matsui, N., \& Ikemoto, Y. (2013). Dynamics of Poverty in Rural Bangladesh. Springer. 
Ramachandran, H. (2014). Urbanisation: A Solution to Poverty? Social Change, 44 (4), 593-603.

Ravallion, M., Chen, S. \& Sangraula, P., 2008. New Evidence on the Urbanization of Global Poverty. Policy Research Working Papers, World Bank.

Rodríguez-Pose, A., \& Hardy, D. (2015). Addressing poverty and inequality in the rural economy from a global perspective. Applied Geography, 61, 11-23.

Sridhar, K. S. (2015). Is Urban Poverty More Challenging than Rural Poverty? A Review. Environment and Urbanization Asia, 6 (2).

Sugiri, A. (2009). Redressing Equity Issues in Natural Resource-Rich Regions: A Theoretical Framework for Sustaining Development in East Kalimantan, Indonesia. In E. L. Weber, ed. Environmental Ethics, Sustainability and Education. Oxford: InterDisciplinary Press, 107-134.

United Nations Population Fund (UNFPA). (2007). State of world population 2007 Unleashing the Potential of Urban Growth.

Wallenborn, M. (2009). Skills development for poverty reduction (SDPR): The case of Tajikistan. International Journal of Educational Development, 29, 550-557.

Wratten, E. (1995). Conceptualizing urban poverty. Environment and Urbanization, 7 (1), 11-38.

Yunus, H. S. (2008). Dinamika Wilayah PeriUrban: Determinan Masa Depan Kota. Yogyakarta: Pustaka Pelajar. 